Please do not remove this page

RMIT

UNIVERSITY

\title{
A comprehensive ovine model of blood transfusion
}

Simonova, G; Tung, John; Fraser, John; Do, H; Staib, A; Chew, M; Dunster, Kimble

https://researchrepository.rmit.edu.au/esploro/outputs/9921859604101341/filesAndLinks?institution=61RMIT_INST\&index=null

Simonova, G., Tung, J., Fraser, J., Do, H., Staib, A., Chew, M., Dunster, K., Glenister, K., Jackson, D., \& Fung, Y. (2014). A comprehensive ovine model of blood transfusion. Vox Sanguinis, 106(2), 153-160.

https://doi.org/10.1111/vox.12076

Document Version: Accepted Manuscript

Published Version: https://doi.org/10.1111/vox.12076

Repository homepage: https://researchrepository.rmit.edu.au

(C) 2013 International Society of Blood Transfusion

Downloaded On 2023/04/26 17:37:18 +1000

Please do not remove this page 
Thank you for downloading this document from the RMIT Research Repository.

The RMIT Research Repository is an open access database showcasing the research outputs of RMIT University researchers.

RMIT Research Repository: http://researchbank.rmit.edu.au/

\section{Citation:}

Simonova, G, Tung, J, Fraser, J, Do, H, Staib, A, Chew, M, Dunster, K, Glenister, K, Jackson, D and Fung, Y 2014, 'A comprehensive ovine model of blood transfusion', Vox Sanguinis, vol. 106, no. 2, pp. 153-160.

See this record in the RMIT Research Repository at:

https://researchbank.rmit.edu.au/view/rmit:23816

Version: Accepted Manuscript

Copyright Statement: (C) 2013 International Society of Blood Transfusion

Link to Published Version:

http://dx.doi.org/10.1111/vox.12076 


\section{A comprehensive ovine model of blood transfusion}

Gabriela Simonova ${ }^{1,2}$, John-Paul Tung ${ }^{1,2}$, John F Fraser ${ }^{1}$, Hong Lien Do ${ }^{1}$, Andrew Staib ${ }^{3}$, Michelle S Chew ${ }^{4}$, Kimble R Dunster ${ }^{1,5}$, Kristen Glenister ${ }^{6}$, Denise Jackson ${ }^{7}$, Yoke Lin Fung ${ }^{1}$

${ }^{I}$ Critical Care Research Group, The University of Queensland and The Prince Charles Hospital, Brisbane, QLD, Australia

${ }^{2}$ Research and Development, Australian Red Cross Blood Service, Brisbane, QLD, Australia

${ }^{3}$ Emergency Department, Princess Alexandra Hospital, Brisbane, QLD, Australia

${ }^{4}$ Department of Intensive Care and Perioperative Medicine, Skåne University Hospital Malmö, Sweden

${ }^{5}$ Faculty of Science and Engineering, Queensland University of Technology, Brisbane, QLD, Australia

${ }^{6}$ Research and Development, Australian Red Cross Blood Service, Melbourne, VIC, Australia

${ }^{7}$ School of Medical Sciences, Royal Melbourne Institute of Technology, University, VIC, Australia

\section{Address correspondence to:}

Ms Gabriela SIMONOVA

Critical Care Research Group

University of Queensland \& The Prince Charles Hospital

3rd Floor Clinical Sciences Building

The Prince Charles Hospital

Rode Rd, Chermside, QLD 4032

Tel: +61731394733

Fax: +61 731396120

Email: g.simonova@uq.edu.au

Supported by the Critical Care Research Group (CCRG), Queensland Emergency Medicine Research Foundation (QEMRF) and the Australian Red Cross Blood Service (ARCBS).

The authors declare that they have no conflict of interest relevant to the manuscript submitted to TRANSFUSION. 


\begin{abstract}
Background: The growing awareness of the transfusion associated morbidity and mortality necessitates investigations into the underlying mechanisms. Small animal have been the dominant transfusion models but have significant limitations. This study sought to develop and evaluate a comprehensive large animal (ovine) model of transfusion that would encompass: blood collection, processing, storage, compatibility testing and transfusion outcomes.
\end{abstract}

Study design and methods: Twenty-four units of whole blood were collected from 12 healthy Merino adult male sheep and processed into packed red blood cells (PRBC). Baseline haematological values of sheep blood and PRBC were analysed. Biochemical changes in ovine PRBC packs were monitored and characterized during 42 days of storage. Immunologic compatibility of the blood was confirmed with sera from potential recipient sheep using a saline agglutination crossmatch. Following confirmation of compatibility, 2 units of PRBC were transfused into each recipient sheep $(\mathrm{n}=12)$.

Results: Methods for collection, processing, crossmatching and transfusion of sheep blood were established. Ovine RBCs are smaller, higher in number, but have similar mean cell haemoglobin concentration than human RBCs. The ovine PRBC showed improved storage properties in SAGM when compared with previous studies of human PRBC. Although haemolysis was at the upper limit at day 42, ovine PRBC met the human PRBC specifications. In all, 77 compatibility tests were performed and $18.2 \%$ were incompatible. No adverse reaction occurred in recipient sheep during blood transfusion.

Conclusion: These findings validate the application of the ovine model for future blood transfusion studies and demonstrate the need of compatibility testing in animal models.

Key Words: ovine model, blood transfusion, storage lesion, compatibility test 


\section{Introduction}

Blood transfusion is an essential part of modern medicine. While blood transfusion can be life-saving it is not without risk [1]. Specific pathologies associated with transfusion include transfusion-related acute lung injury (TRALI), transfusion related immunomodulation (TRIM), circulatory overload, bacterial infections and haemolytic transfusion reactions are complications that can lead to deleterious outcomes [2-4]. Additionally, there is a growing body of evidence indicating an association between transfusion, especially of aged/stored blood products, and increased levels of morbidity and mortality in patients $[5,6]$. This has prompted the development of multicentre clinical trials that aim to answer this question from a clinical perspective. Such trials, however, will not shed any light on the underlying pathological mechanisms.

Ethical issues limit the research that can be undertaken in humans, necessitating the development of clinically relevant animal models of transfusion to investigating the mechanism of adverse transfusion reactions and poor clinical outcomes. However, the value of any information generated from animal models, is defined by the scope as well of limitations of the animal model. Murine models have been used extensively because of their relatively low cost and the ease of accessibility. However, the small size of mice and rats limits the volume of blood samples that can be collected and prevents the use of the standard blood collection packs. In addition, the lifespan of murine red blood cells (RBCs) is about half that of humans $[7,8]$. We also noted the absence of pre-transfusion compatibility testing in many animal transfusion studies. These factors fuelled our quest to develop a comprehensive and clinically relevant in vivo transfusion model that would support transfusion research investigation by mimicking the human cycle of blood donation, processing, compatibility testing and monitoring of transfusion outcomes. 
This study elected to develop a clinically relevant model using sheep because their anatomy, hemodynamic and microcirculatory characteristics and RBCs lifespan are very similar to humans ( 120 days) [9-12]. 


\section{Methods}

This study was approved by the University Animal Research Ethics Committee of the Queensland University of Technology and University of Queensland, and all experiments were conducted in accordance with the Australian Code of Practice for the Care and Use of Animals for Scientific Purposes.

\section{Ovine blood collection protocol}

Two units of whole blood were collected from each of twelve male Merino sheep aged between 1-3 years and weighing of $40.7 \pm 1.7 \mathrm{~kg}(\operatorname{mean} \pm \mathrm{SD})$ as part of another haemorrhage study (Vox ref). In brief, the sheep were instrumented under ketamine/midazolam anesthesia and monitored for arterial blood pressure, continuous cardiac output, mixed venous oxygen saturation and temperature. Sheep were ventilated throughout the experiment with a Hamilton Galileo ventilator at $12-15$ breaths per minute.

Following a period of stabilisation two units of whole blood $(400 \pm 20 \mathrm{~mL}$ per unit) were collected from each sheep via a $8.5 \mathrm{G}$ venous sheath placed in the left internal jugular vein at flow rate $80-100 \mathrm{~mL} / \mathrm{min}$ for $5-8 \mathrm{mins} / \mathrm{bag}$ into separate Leukotrap WB blood packs (Pall Medical, UK), containing 63mL of citrate, phosphate and dextrose (CPD) as an anticoagulant solution each. Additionally, a tube of Ethylenediaminetetraacetic acid (EDTA) blood (Greiner Bio-one Vacuette ${ }^{\circledR}$, Thailand) was collected from the diversion pouch of the blood pack for full blood counts.

\section{Processing and storage of donor blood}

After 2 hours incubation at room temperature the whole blood was passed through the attached leukofilter. As ovine RBC are significantly smaller the whole blood was centrifuged at 5000g for 45 minutes and separated into plasma and packed red blood cell (PRBC) using a 
manual Fenwal ${ }^{\circledR}$ plasma extractor (Baxter, USA). The ovine PRBC (ovPRBC) were suspended in saline-adenine-glucose-mannitol (SAGM) additive solution, and stored under standard storage conditions at $2-6^{0} \mathrm{C}$ prior to transfusion.

\section{Quality assessment}

The EDTA blood samples $(\mathrm{n}=12)$ and a segment from the corresponding prepared ovPRBC units $(\mathrm{n}=24)$ were evaluated for $\mathrm{pH}$, potassium, glucose and lactate using a Radiometer ABL825 blood gas analyser (Radiometer, Copenhagen, Denmark). The RBC volume, haemoglobin and haematocrit, mean corpuscular volume (MCV), mean corpuscular haemoglobin $(\mathrm{MCH})$ and mean corpuscular haemoglobin concentration $(\mathrm{MCHC})$ were also measured using the Beckman and Coulter ${ }^{\circledR}$ Act diff ${ }^{\mathrm{TM}}$ haematology analyser (Beckman Coulter Inc, Ireland). Subsequently, samples were aseptically collected from ovPRBC units were analysed on days $1,5,7,14,21,28,35$ and 42 to determine the effects of storage. The degree of haemolysis in stored samples was determined by measuring supernatant haemoglobin concentration after centrifugation of ovPRBC using a portable HemoCue ${ }^{\circledR} \mathrm{Hb}$ $201^{+}$Photometer System (HemoCue AB, Ängelholm, Sweden) [13]. The percentage haemolysis was calculated as follows: (100-Hct) x free plasma $\mathrm{Hb}(\mathrm{g} / \mathrm{L}) /$ total $\mathrm{Hb}(\mathrm{g} / \mathrm{L})$.

\section{Compatibility testing}

Compatibility testing between donor ovPRBC and recipient sheep RBC was performed to avoid haemolytic transfusion reactions. Compatibility was confirmed by four procedures involving two drops of recipient sheep sera mixed with 1 drop of 5\% donor sheep RBC in phosphate buffered saline (PBS) each.

(i) Immediate centrifugation at $390 \mathrm{~g}$ for $15 \mathrm{sec}$ and examined macroscopically for agglutination. The strength of agglutination was scored on a scale of 0-4 [14]. 
(ii) Incubated at room temperature for 30min, then centrifuged as above and examined macroscopically for agglutination.

(iii) Incubated at $37^{\circ} \mathrm{C}$ for 30 minutes, and then centrifuged and examined.

(iv) Tube (iii) was then centrifuged at $540 \mathrm{~g}$ for $1 \mathrm{~min}$; the supernatant was removed and replaced by a drop of $10 \%$ albumin and incubated at $37^{\circ} \mathrm{C}$ for another 30 minutes before examination macroscopically for agglutination.

The ovPRBC was considered compatible when all 4 tests were negative [Fig 1].

\section{Ovine Blood Transfusion}

Two units of compatible ovPRBC were transfused into sheep that had been bled of $30 \%$ of their blood volume. This was followed by $4 \%$ albumin to achieve volume replacement. Six sheep received fresh (<5-day old) ovPRBC and another six received stored (35-42 days old) ovPRBC. Transfused sheep were continuously monitored for 4 hours post-transfusion.

\section{Statistics}

All data are presented as mean \pm standard deviation $(\mathrm{SD})$ of the mean and ranges. Significance between groups was determined based on planned comparisons using a 1-way ANOVA. Posterior Bonferroni's test was performed to determine difference between groups and baseline (GraphPad Prism6). $P$ values of less than 0.05 were considered to be statistically significant. 


\section{Results}

\section{Ovine haematology}

Baseline EDTA blood samples from 12 healthy male Merino sheep were analysed and compared with healthy human male values (Table1). The red blood cell counts (RBCC) in ovine blood was higher $\left(9.85-13.52 \times 10^{12} / \mathrm{L}\right)$ compared with that of humans $(4.60-6.00$ $\left.\mathrm{x} 10^{12} / \mathrm{L}\right)$. The range of measured haemoglobin $(\mathrm{Hb})$ and haematocrit $(\mathrm{Hct})$ levels in sheep blood overlapped that of humans $(115-156 \mathrm{~g} / \mathrm{L}$ vs. $140-180 \mathrm{~g} / \mathrm{L}$ and $35.0-48.4 \%$ vs. $40-54 \%$ respectively). Mean cell volume (MCV) and mean cell haemoglobin $(\mathrm{MCH})$ values were considerably lower from human (31.6-37.9fL vs. 80-100fL; 10.8-14.1pg vs. 26-32pg respectively). The range of ovine mean cell haemoglobin concentration (MCHC) was similar to that of humans (314-342g/L vs. 320-360g/L).

\section{Quality assessment of ovPRBC units}

Twenty-four ovPRBC units were analysed and compared with human PRBC units (Table1). According to current standard requirements by Council of Europe Guideline the $\mathrm{Hb}$ level should be higher than $45 \mathrm{~g}$ and the Hct level between 50-70\% in human PRBC units [15]. The $\mathrm{Hb}$ level of ovPRBC (136-184g/L) surpassed that requirement but the Hct (39.0-71.3\%) was slightly below to the required level. In spite of these differences ovPRBC haematology parameters were proportional to the human equivalent.

\section{Storage-related changes in ovPRBC units}

In this study, we also examined the following storage lesion parameters: haemolysis, potassium, glucose, lactate and $\mathrm{pH}$ in 10 units of ovPRBC over 42 days. Significant haemolysis was evident in ovPRBC from day $35(P<0.0001 v s$. day 1$)$ and was further increased at day 42 [Fig 2A]. From day 5 the potassium level of sheep PRBC steadily 
increased to peak at $6.77 \mathrm{mmol} / \mathrm{L}$ on day 28 after which it was relatively stable [Fig $2 \mathrm{~B}$ ]. There was a statistically significant decline in glucose levels evident after day 14 of storage $(P=0.009$ vs. day 1$)[$ Fig $2 \mathrm{C}]$. This corresponded with a significant increase in lactate levels that was evident from day $28(P=0.0028$ vs. day 1$)$ [Fig $2 \mathrm{D}$ ]. The $\mathrm{pH}$ on day 1 was $7.014 \pm 0.047$ and remained unchanged throughout the 42 -day storage period ( $P=0.999$ vs. day 1) [data not shown].

\section{Blood compatibility testing}

In the total group, 77 compatibility tests were performed with sera from 24 potential male recipient sheep. Sixty-three of $77(81.83 \%)$ were compatible and 14 (18.18\%) were incompatible.

\section{Ovine Blood Transfusion}

After compatibility confirmation, 24 units of whole blood were transfused into 12 sheep recipients ( 2 units per sheep). During the 4 hours of monitoring post-transfusion, there was no evidence of any symptoms of adverse reaction (i.e. fever, tachycardia, hypotension, hypoxia or bleeding). 


\section{Discussion}

Blood transfusion is a life-saving therapy used widely throughout clinical practice however it is not without risk. An increasing body of evidence has highlighted the noninfectious risks of transfusion, particularly of stored blood products $[16,17]$. While clinical trials investigating the possible association between age of blood and poor clinical outcomes will inform changes to clinical practice, clinically relevant animal models of transfusion are necessary to elucidate the underlying mechanisms. Central to the clinical validity of such models are the accurate assessment of the scope and the limitations of each specific animal model. Small animals (mice, rats, guinea pigs) have been used extensively as transfusion models [8, 18-21]. However, they present many anatomical, physiological and immunological differences compared to humans [22]. For example, rodents RBCs have significantly shorter lifespan than human and sheep RBCs (Table 2). For this reason, rodent blood undergoes a more rapid rate of deterioration under storage conditions compared to human erythrocytes and influences the duration of storage $[7,8,19,23]$. In addition, the smaller size and lower blood volume dictates the use of centrifuge tubes rather than blood packs in collection, processing and storage of rodent blood (Table 2). This and restrictions on sampling volume, repeated measurements and follow-up also limit their clinical relevance.

An ideal and clinically relevant animal model of blood transfusion would have anatomical and size similarities compared to humans, as well as comparative haematological and biochemistry values, analogous collection and processing protocols, not to mention the ease and expanse of care. Ovine models have been used extensively in medical research [24, 25] as they having comparable size and anatomical similarities [26] to humans providing good surgical accessibility and possibilities for multiple sampling and follow-up. They also have comparative plasma and tissue pharmacokinetics [27], pulmonary circulation [28] and a placid nature, which is extremely useful during long in vivo studies [29]. Furthermore, as 
their size and blood volume is similar to humans it is possible to collect a whole unit of blood in collection bags identical to those used for human blood donors.

This study established normal haematology and biochemistry ranges for the Merino breed of sheep. These values were compared against those reported previously for humans. Ovine RBCs are smaller and more numerous than human RBCs. This corresponded with a lower range for ovine $\mathrm{MCH}$ compared to humans. In contrast, the range of ovine $\mathrm{Hb}, \mathrm{Hct}$ and MCHC overlapped with the human normal range. These results together with the fact that the ovine RBC life span is very similar to that of human reveals some of the advantages ovine models have over other small animal models.

To determine if ovine PRBC would adequately mimic human PRBC in the study of the effects of transfusing stored blood, we also monitored haematological and biochemical properties of ovine PRBC over 42-day storage period (Figure 2). Similar to human PRBC units, the rate of haemolysis evident in SAGM-containing ovPRBC units increased during storage. According to the Council of Europe Guideline [15], the haemolysis rate of human PRBC units at out-date (42 days) should not exceed $0.8 \%$. In this study haemolysis on day 42 was $0.81 \% \pm 0.29$, pointing towards a slightly accelerated rate of storage lesion development in ovPRBCs. In vivo survival of lamb PRBC after 40 day storage and transfusion [30] have been reported earlier. However, further studies are required to establish the viability and osmotic fragility of adult sheep PRBC during and after 42-day storage period.

Potassium levels in stored human blood products increase over time, which may lead to severe levels of hyperkalemia (potassium $>5.5 \mathrm{mmol} / \mathrm{L}$ ), and this limits the shelf life of stored PRBC $[23,31]$. Potassium in PRBC units is derived from RBC leakage, and levels in human PRBC range from 4 to 40mmol/L [32]. Ovine RBCs appear to be more stable as the potassium levels were considerably lower even on day 42 . 
The glucose levels decreased and lactic acid increased over time in ovPRBC but these changes were milder than what has been reported in human PRBC [23, 33]. In line with this the $\mathrm{pH}$ of ovine PRBC was stable over the entire storage period. Together these results suggest that metabolism of ovPRBC is slower. However, detailed investigation of ovPRBC biochemical changes, primarily adenosine triphosphate (ATP) and 2,3-diphosphoglycerate (2,3-DPG) level are required to confirm this.

Pre-transfusion compatibility testing and blood typing in humans is vital and routine practise. However, in animal research it is primarily focused on high value animals, such as pets and horses. Our literature search found only rare reports of ovine pre-transfusion testing and the methodology listed contained little detail [34-36]. The diversity of blood groups in sheep and the lack of commercially available blood-typing reagents make complete typing and matching difficult. Therefore, we developed a modified saline agglutination method that can be easily added to the research protocol. Using this technique $18.2 \%$ of cross matches were found to be not compatible. This data challenges the presumption that single, unmatched whole blood transfusions are generally safe and well tolerated within an animal species. This unexpected high frequency of incompatibility emphasises importance pretransfusion compatibility testing especially in transfusion models.

As discussed above an ovine model provides many advantages for the study of transfusion associated injuries, however its main limitation is that ovine RBCs are significantly smaller compared to that of humans [9, 37-40]. The smaller size of ovine RBC equates to a significantly higher surface area to volume ratio, and as a result ovine RBCs do not aggregate or deform as readily as RBCs of other species [41].

In summary, this study presents a comprehensive validated ovine model of blood transfusion. Our results confirm the use of human blood bags for sheep blood collection with analogous blood bag processing, compatibility checking and transfusion procedures. In 
addition, we established baseline haematological and biochemical parameters for healthy adult male Merino sheep and ovine PRBC units of various ages, and demonstrated the value of pre-transfusion compatibility testing. Together, these findings validate the application of the sheep model for blood transfusion studies and identify the advantages and limitations of an ovine transfusion model to assist future investigators design and select appropriate in vivo transfusion models.

\section{Acknowledgement}

This work was funded by the Queensland Emergency Medicine Research Foundation (QEMRF), the Australian Red Cross Blood Service (ARCBS) and the National Health and Medical Research Council (NHMRC). JFF is supported by Health Research Fellowship from the Office of Health and Medical Research, Queensland Health. The authors are deeply grateful to William Sommers and Peter Lindenberg for the skilful sheep handling. 


\section{References}

1. Vamvakas EC, Blajchman MA: Transfusion-related mortality: the ongoing risks of allogeneic blood transfusion and the available strategies for their prevention. Blood 2009, 113(15):3406-3417.

2. Tung JP, Fung YL, Nataatmadja M, Colebourne KI, Esmaeel HM, Wilson K, Barnett AG, Wood P, Silliman CC, Fraser JF: A novel in vivo ovine model of transfusion-related acute lung injury (TRALI). Vox Sang 2011, 100(2):219230.

3. Vamvakas EC, Blajchman MA: Transfusion-related immunomodulation (TRIM): an update. Blood reviews 2007, 21(6):327-348.

4. Popovsky MA: Pulmonary consequences of transfusion: TRALI and TACO. Transfusion and apheresis science : official journal of the World Apheresis Association : official journal of the European Society for Haemapheresis 2006, 34(3):243-244.

5. Bhaskar B, Dulhunty J, Mullany DV, Fraser JF: Impact of blood product transfusion on short and long-term survival after cardiac surgery: more evidence. The Annals of thoracic surgery 2012, 94(2):460-467.

6. Hebert PC, Wells G, Blajchman MA, Marshall J, Martin C, Pagliarello G, Tweeddale $\mathrm{M}$, Schweitzer I, Yetisir E: A multicenter, randomized, controlled clinical trial of transfusion requirements in critical care. Transfusion Requirements in Critical Care Investigators, Canadian Critical Care Trials Group. The New England journal of medicine 1999, 340(6):409-417.

7. Gilson CR, Kraus TS, Hod EA, Hendrickson JE, Spitalnik SL, Hillyer CD, Shaz BH, Zimring JC: A novel mouse model of red blood cell storage and posttransfusion in vivo survival. Transfusion 2009, 49(8):1546-1553.

8. d'Almeida MS, Jagger J, Duggan M, White M, Ellis C, Chin-Yee IH: A comparison of biochemical and functional alterations of rat and human erythrocytes stored in CPDA-1 for 29 days: implications for animal models of transfusion. Transfus Med 2000, 10(4):291-303.

9. Mock DM, Lankford GL, Burmeister LF, Strauss RG: Circulating red cell volume and red cell survival can be accurately determined in sheep using the [C14]cyanate label. Pediatric research 1997, 41(6):916-921.

10. EM T: Red cell life span in young and adult sheep. Res Vet Sci 1963, 4:11-23.

11. Brace RA, Langendorfer C, Song TB, Mock DM: Red blood cell life span in the ovine fetus. Am J Physiol Regul Integr Comp Physiol 2000, 279(4):R1196-1204.

12. Giles RC, Jr., Berman A, Hildebrandt PK, McCaffrey RP: The use of 51Cr for sheep red blood cell survival studies. Proc Soc Exp Biol Med 1975, 148(3):795-798.

13. Janatpour KA, Paglieroni TG, Crocker VL, DuBois DJ, Holland PV: Visual assessment of hemolysis in red blood cell units and segments can be deceptive. Transfusion 2004, 44(7):984-989.

14. Banks AAoB: AABB Technical Manual, 12th edition edn. Bethesda: American Association of Blood Banks; 1996.

15. Council of Europe. Guide to the preparation, use and quality assurance of blood components. In., 16th edn. Strasbourg, France: Council of Europe; 2011.

16. Tung JP, Fraser JF, Nataatmadja M, Colebourne KI, Barnett AG, Glenister KM, Zhou AY, Wood P, Silliman CC, Fung YL: Age of blood and recipient factors 
determine the severity of transfusion-related acute lung injury (TRALI). Crit Care 2012, 16(1):R19.

17. Lelubre C, Piagnerelli M, Vincent JL: Association between duration of storage of transfused red blood cells and morbidity and mortality in adult patients: myth or reality? Transfusion 2009, 49(7):1384-1394.

18. Nicholson SE, Johnson RA, Craig T, Myers JG, Durante W, Stewart RM, Johnson FK: Transfusion-related acute lung injury in a rat model of traumahemorrhage. J Trauma 2011, 70(2):466-471.

19. Baek JH, D'Agnillo F, Vallelian F, Pereira CP, Williams MC, Jia Y, Schaer DJ, Buehler PW: Hemoglobin-driven pathophysiology is an in vivo consequence of the red blood cell storage lesion that can be attenuated in guinea pigs by haptoglobin therapy. J Clin Invest 2012, 122(4):1444-1458.

20. Hendrickson JE, Hod EA, Hudson KE, Spitalnik SL, Zimring JC: Transfusion of fresh murine red blood cells reverses adverse effects of older stored red blood cells. Transfusion 2011, 51(12):2695-2702.

21. Machiedo GW, Zaets SB, Berezina TL, Xu DZ, Feketova E, Spolarics Z, Deitch EA: Trauma-hemorrhagic shock-induced red blood cell damage leads to decreased microcirculatory blood flow. Crit Care Med 2009, 37(3):10001010.

22. Harris A: Towards an ovine model of cystic fibrosis. Human molecular genetics 1997, 6(13):2191-2194.

23. Makley AT, Goodman MD, Friend LA, Johannigman JA, Dorlac WC, Lentsch AB, Pritts TA: Murine blood banking: characterization and comparisons to human blood. Shock 2010, 34(1):40-45.

24. Fung YL, Diab S, Dunster K, Foley SR, McDonald CI, Passmore M, Platts D, Simonova G, Shekar K, Stewart D et al: Extracorporeal Lessons from Sheep. Vox Sang 2012, 103:11-11.

25. Riedel T, Fraser JF, Dunster K, Fitzgibbon J, Schibler A: Effect of smoke inhalation on viscoelastic properties and ventilation distribution in sheep. Journal of applied physiology: respiratory, environmental and exercise physiology 2006, 101(3):763-770.

26. Bosanquet AG, Goss AN: The sheep as a model for temporomandibular joint surgery. International journal of oral and maxillofacial surgery 1987, 16(5):600603.

27. Glanzmann TM, Zellweger MP, Borle F, Conde R, Radu A, Ballini JP, Jaquet Y, Pilloud R, van den Bergh $\mathrm{H}$, Monnier $\mathrm{P}$ et al: Assessment of a sheep animal model to optimise photodynamic therapy in the oesophagus. Lasers in surgery and medicine 2009, 41(9):643-652.

28. Gao Y, Raj JU: Regulation of the pulmonary circulation in the fetus and newborn. Physiological reviews 2010, 90(4):1291-1335.

29. Adams D, McKinley M, Colditz I, Dart C: The sheep. In: ANZCCART. Adelaide: University of Adelaide; 2009.

30. Baron DM, Yu B, Lei C, Bagchi A, Beloiartsev A, Stowell CP, Steinbicker AU, Malhotra R, Bloch KD, Zapol WM: Pulmonary hypertension in lambs transfused with stored blood is prevented by breathing nitric oxide. Anesthesiology 2012, 116(3):637-647.

31. Smith HM, Farrow SJ, Ackerman JD, Stubbs JR, Sprung J: Cardiac arrests associated with hyperkalemia during red blood cell transfusion: a case series. Anesthesia and analgesia 2008, 106(4):1062-1069, table of contents. 
32. Fleming GM, Remenapp RT, Bartlett RH, Annich GM: Hyperkalemia of the blood-primed ECLS circuit does not result in post-initiation hyperkalemia in infants $<\mathbf{1 0} \mathbf{~ k g}$. Perfusion 2006, 21(3):173-177.

33. Sumpelmann R, Schurholz T, Thorns E, Hausdorfer J: Acid-base, electrolyte and metabolite concentrations in packed red blood cells for major transfusion in infants. Paediatric anaesthesia 2001, 11(2):169-173.

34. McCutcheon S, Alejo Blanco AR, Houston EF, de Wolf C, Tan BC, Smith A, Groschup MH, Hunter N, Hornsey VS, MacGregor IR et al: All clinically-relevant blood components transmit prion disease following a single blood transfusion: a sheep model of vCJD. PloS one 2011, 6(8):e23169.

35. Hunter N, Foster J, Chong A, McCutcheon S, Parnham D, Eaton S, MacKenzie C, Houston F: Transmission of prion diseases by blood transfusion. J Gen Virol 2002, 83(Pt 11):2897-2905.

36. Houston F, Foster JD, Chong A, Hunter N, Bostock CJ: Transmission of BSE by blood transfusion in sheep. Lancet 2000, 356(9234):999-1000.

37. Schalm 0: Schalm's veterinary hematology, 6th edition edn: Wiley-Blackwell; 2010.

38. Plasenzotti R, Stoiber B, Posch M, Windberger U: Red blood cell deformability and aggregation behaviour in different animal species. Clinical hemorheology and microcirculation 2004, 31(2):105-111.

39. Ullrey DE, Miller ER, Long CH, Vincent BH: Sheep Hematology from Birth to Maturity. I. Erythrocyte Population, Size and Hemoglobin Concentration. Journal of animal science 1965, 24:135-140.

40. Yeh E, Pinsky BA, Banaei N, Baron EJ: Hair sheep blood, citrated or defibrinated, fulfills all requirements of blood agar for diagnostic microbiology laboratory tests. PloS one 2009, 4(7):e6141.

41. Gregory TR: Nucleotypic effects without nuclei: genome size and erythrocyte size in mammals. Genome / National Research Council Canada $=$ Genome / Conseil national de recherches Canada 2000, 43(5):895-901.

42. Edmondson PW: Erythrocyte Life-Span, Red Cell Mass and Plasma Volume of Normal Guinea-Pigs as Determined by Use of 51chromium, 32phosphorus Labelled Di-Isopropyl Fluorophosphonate and 131-Iodine Labelled Human Serum Albumin. Brit J Exp Pathol 1963, 44(1):72-\&.

43. Shemin D, Rittenberg D: The life span of the human red blood cell. The Journal of biological chemistry 1946, 166(2):627-636. 


\section{Figure legends}

Figure 1 A range of typical ovine compatibility tests results. $0=$ No agglutination, an even red cell suspension; $1=$ Small agglutinates, with a lot of free red cells; $2=$ Medium size agglutination, clear background; 4 = one solid agglutinate, no free red cells detected.

Figure 2 Characterization of biochemical changes (haemolysis, potassium, glucose, lactate) in ovPRBCs $(\mathbf{n = 1 0})$ during 42 days storage. ${ }^{*} P<0.05$ vs. day 1 for storage duration. The results are mean $\pm \mathrm{SD}$. 


\section{Figure1}

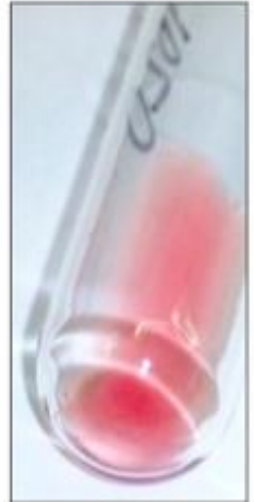

Score $=0$

COMPATIBLE

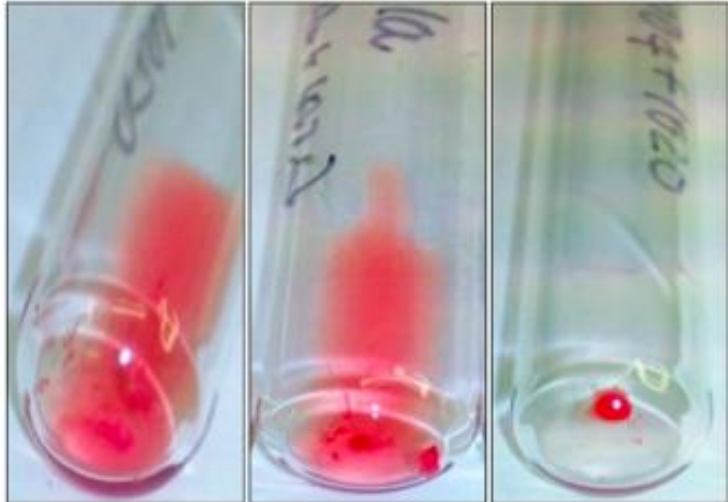

Score $=1 \quad$ Score $=2 \quad$ Score $=4$ 
Figure2

[A]

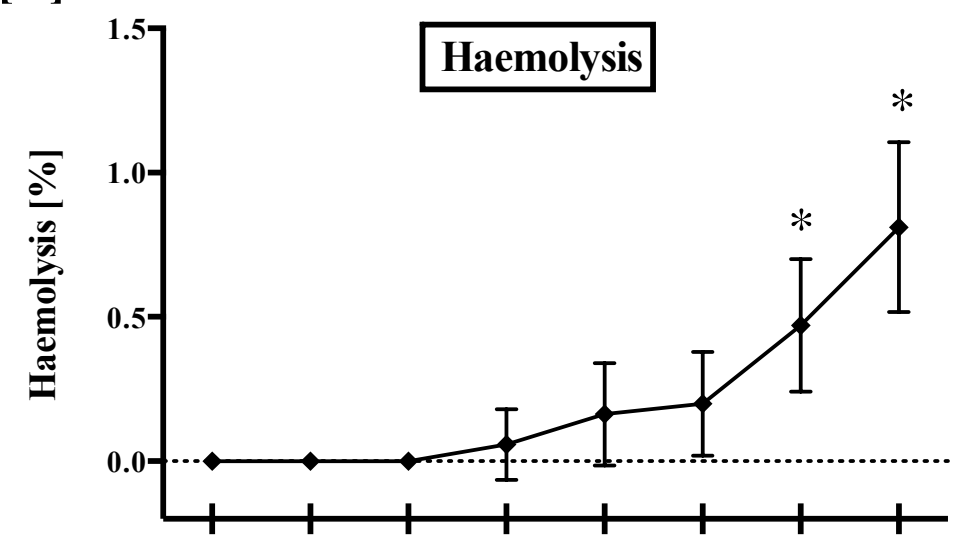

[C]

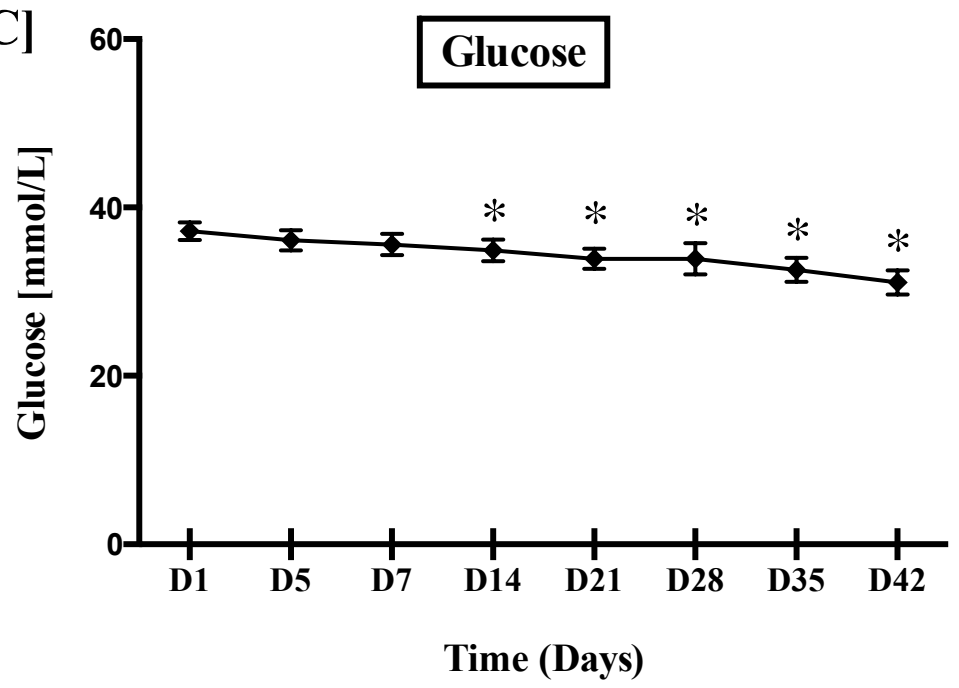

[B]

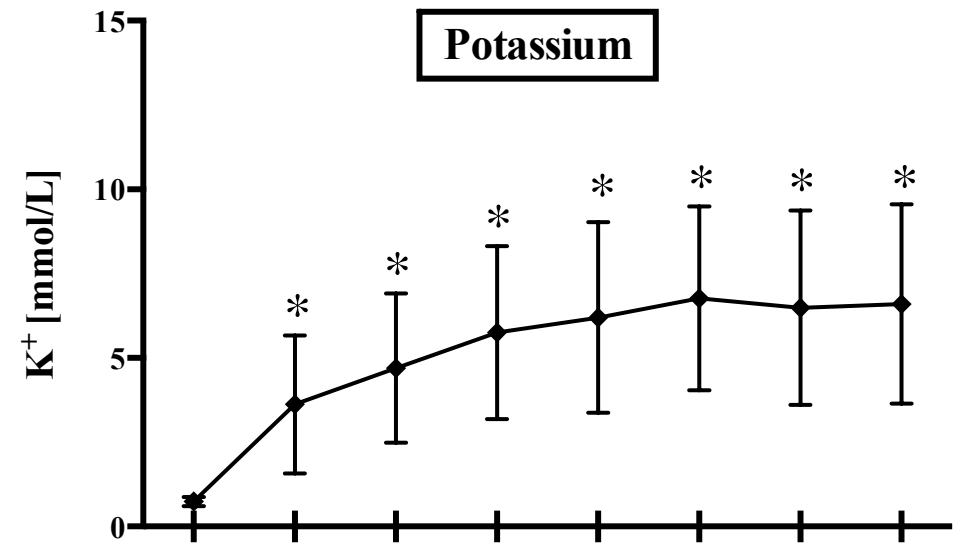

[D]

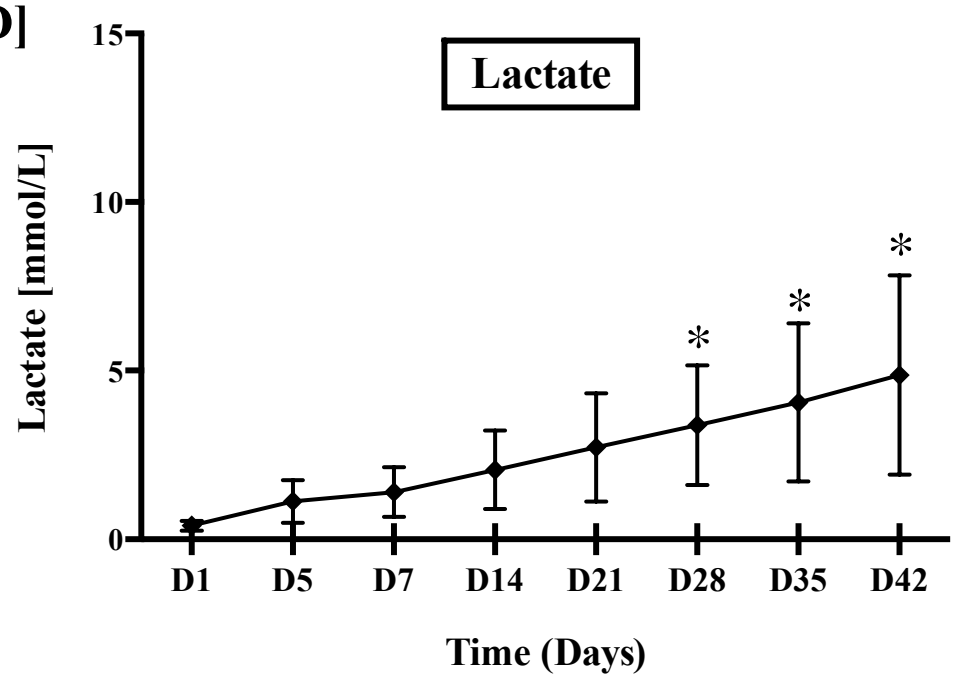


Tables

Table 1

\begin{tabular}{|c|c|c|c|c|c|c|c|c|}
\hline \multirow[b]{2}{*}{ Parameters* } & \multirow[b]{2}{*}{ Unit } & \multirow{2}{*}{$\begin{array}{c}\text { Human } \\
\text { blood }^{\#}\end{array}$} & \multicolumn{2}{|c|}{$\begin{array}{l}\text { Ovine blood } \\
\qquad(n=12)\end{array}$} & \multicolumn{2}{|c|}{$\begin{array}{l}\text { Human PRBC units** } \\
\qquad(\mathrm{n}=15)\end{array}$} & \multicolumn{2}{|c|}{$\begin{array}{c}\text { Ovine PRBC units } \\
\qquad(\mathrm{n}=24)\end{array}$} \\
\hline & & & Mean $( \pm$ SD $)$ & Range & Mean ( $( \pm$ SD) & Range & Mean $( \pm$ SD) & Range \\
\hline RBCC & {$\left[10^{12} / \mathrm{L}\right]$} & $4.60-6.00$ & $11.41( \pm 1.14)$ & $9.85-13.52$ & $6.63( \pm 0.50)$ & $5.84-7.52$ & $13.74( \pm 1.87)$ & $11.28-19.07$ \\
\hline $\mathbf{H b}$ & {$[g / L]$} & $140-180$ & $131.27( \pm 14.4)$ & $115-156$ & $198( \pm 10.74)$ & $178-215$ & $158.83( \pm 15.37)$ & $136-184$ \\
\hline Het & {$[\%]$} & $40-54$ & $39.93( \pm 4.46)$ & $35.0-48.4$ & $60.49( \pm 0.03)$ & $53.9-65.1$ & $48.49( \pm 7.68)$ & $39.0-71.3$ \\
\hline MCV & {$[\mathrm{fL}]$} & $80-100$ & $34.99( \pm 1.56)$ & $31.6-37.9$ & $91.53( \pm 5.30)$ & $79.7-102.0$ & $35.25( \pm 1.63)$ & $32.2-38.2$ \\
\hline MCH & [pg] & $26-32$ & $11.68( \pm 0.89)$ & $10.8-14.1$ & $29.97( \pm 1.63)$ & $26.2-33.9$ & $11.9( \pm 0.48)$ & $11.2-12.7$ \\
\hline МСНС & {$[\mathrm{g} / \mathrm{L}]$} & $320-360$ & $327( \pm 8.25)$ & $314-342$ & $327.73( \pm 8.30)$ & $310-337$ & $329.08( \pm 27.34)$ & $249-350$ \\
\hline
\end{tabular}

Table 1 Normal hematology values for healthy adult male sheep and fresh ovine PRBC. ${ }^{*} \mathrm{RBCC}=$ red blood cell count; Hb = hemoglobin;

$\mathrm{Hct}=$ haematocrit $\mathrm{MCV}=$ mean cell volume $\mathrm{MCH}=$ mean cell hemoglobin; $\mathrm{MCHC}=$ mean cell hemoglobin concentration. ${ }^{\#}$ From Bernadette

F. Rodak GAF \& Elaine Keohane: Hematology: Clinical Principles and Applications, $4^{\text {th }}$ Edition edn: Elsevier. ${ }^{* *}$ Unpublished data provided by Kristen Glenister, Research and Development, Australian Red Cross Blood Service, Melbourne. 
Table 2

\begin{tabular}{lccccc}
\hline & Mice & Rat & Guinea pig & Sheep & Human \\
\cline { 2 - 6 } Size & $20-40 \mathrm{~g}$ & $250-520 \mathrm{~g}$ & $950-1060 \mathrm{~g}$ & $30-60 \mathrm{~kg}$ & $60-80 \mathrm{~kg}$ \\
Blood volume & $1.2-2.4 \mathrm{~mL}$ & $16-32 \mathrm{~mL}$ & $35-50 \mathrm{~mL}$ & $2-4 \mathrm{~L}$ & $4.4-5 \mathrm{~L}$ \\
Red cell life & 42 days [42] & 65 days [42] & 79 days [42] & $\sim 120$ days [9- & 120 days [43] \\
Span & & & Small blood & Blood packs & Blood packs \\
Blood & Microtubes & Microtubes & bags (150mL) & $(400-600 \mathrm{~mL})$ & (400-600mL) \\
collection & & & 28 days [19] & N/A & 42 days [15] \\
Storage lesion & 7 days [7] & 7 days [8] & 28 & & \\
\hline
\end{tabular}

Table 2 Benefits of an ovine model of transfusion

\begin{abstract}
Abbreviations
TRALI $=$ transfusion-related acute ling injury, TRIM = transfusion-related immunomodulation, $\mathrm{PRBC}=$ packed red blood cell, $\mathrm{ATP}=$ adenosine triphosphate 2,3-DPG = 2,3-diphosphoglycerate
\end{abstract}

